\title{
Chronic hypercapnia and radiological changes in the pituitary fossa
}

\author{
D A G NEWTON, I BONE, AND G BONSOR \\ From the Medical and Radiological Divisions, St James's University Hospital, Leeds, UK
}

Newton, D A G, Bone, I, and Bonsor, G (1978). Thorax, 33, 684-688. Chronic hypercapnia and radiological changes in the pituitary fossa. A consecutive series of ten patients with chronic bronchitis and hypercapnia were studied. All seven patients with chronic hypercapnia and one patient with intermittent hypercapnia showed evidence on skull radiographs of raised intracranial pressure.

In five male and three female chronic bronchitics matched for age and ventilatory impairment, but without hypercapnia, no such radiological abnormalities were shown.

The clinical significance and pathophysiology of this hitherto unreported finding is discussed. It would appear that in some cases the chronicity of hypercapnia may be diagnosed from a radiograph of the pituitary fossa.

We have had the opportunity to study two unusual patients with documented hypercapnia present for more than ten years. Both patients had visual complications from raised intracranial pressure secondary to cerebral oedema, and both were found to have radiological abnormalities of the pituitary fossa. These cases have been reported in detail elsewhere (Newton and Bone, 1978) and are cases 6 and 7 in this report.

As we were unaware of skull radiographic abnormalities occurring in chronic hypercapnia, we decided to assess the radiographs of a further eight patients with hypercapnia seen over the past two years.

\section{Methods}

Patients with chronic bronchitis (Medical Research Council, 1965) of either sex, attending hospital, who had been shown to have hypercapnia on at least three occasions over a minimum period of six months, were studied. Radial arterial blood samples were taken in a heparinised (5000 units/ $\mathrm{ml}$ ) plastic syringe and analysed within five minutes on an IL 227 blood gas analyser. Each patient also had two mixed venous carbon dioxide measurements $\left(\mathrm{PvCO}_{2}\right)$ on one outpatient visit (Campbell and Howell, 1960). Other investigations include haemoglobin $(\mathrm{Hb})$, packed cell volume (PCV), and clinical examination that included a full neurological examination and measurement of arterial blood pressure.

During the period of the study three patients were outpatients and the remainder were first seen as inpatients.

No patient had been on steroids for more than one month and all had airflow obstruction unresponsive to steroids as judged by spirometry. Spirometry was performed on a Vitalograph and normal values were taken from Cotes (1973). The best of three forced expired volume in one second $\left(\mathrm{FEV}_{1}\right)$ and vital capacity (VC) manoeuvres were recorded.

A lateral radiograph of the skull and a coned view of the pituitary fossa were taken on each patient. The films were assessed by a neuroradiologist who was unaware of the arterial carbon dioxide tension of the patient. The abnormalities were scored as follows: thinning of lamina dura = $A$; erosion of lamina dura of dorsum $\operatorname{sellae}=\mathbf{B}$; and erosion of floor of pituitary fossa $=\mathrm{C}$.

Selected examples of abnormal radiographs are shown (figs 1, 2, and 3).

\section{Results}

There were five male and five female patients with a mean age of 58; seven of the patients were chronically hypercapnic $\left(\mathrm{PaCO}_{2}>6.7 \mathrm{kPa}\right.$, $>50 \mathrm{mmHg}$ ), and three were intermittently hyper- 


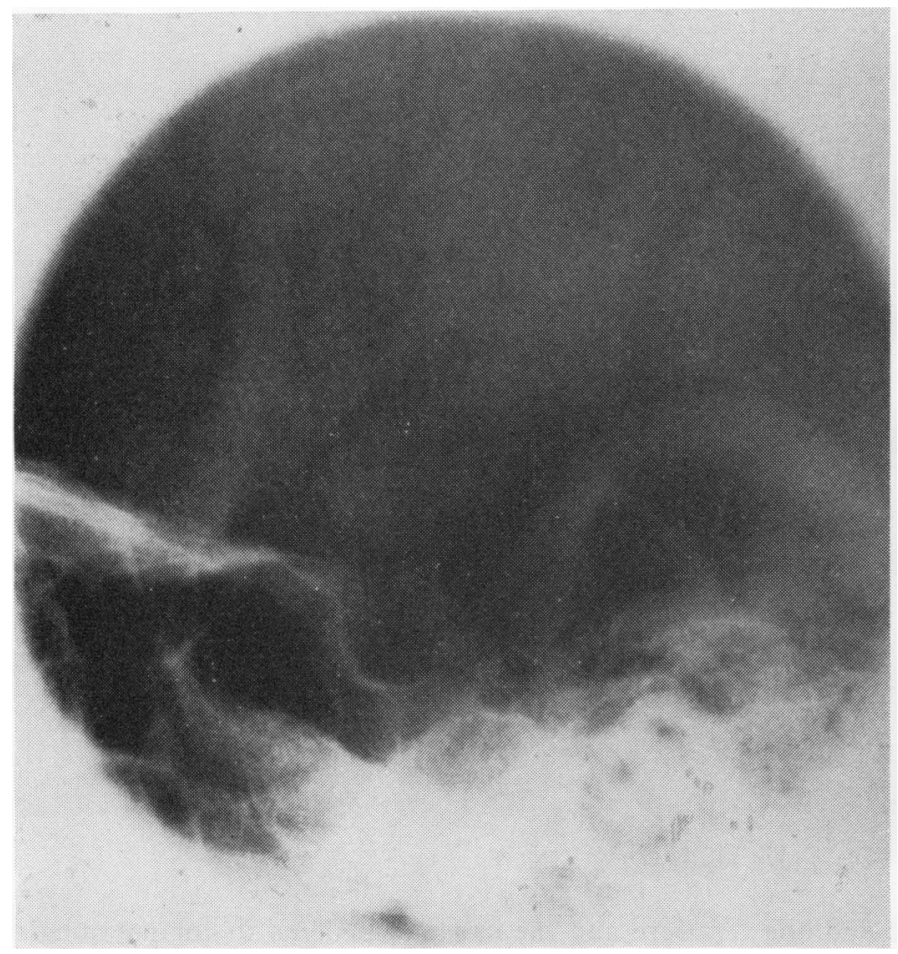

Fig 1 Patient No 3. Erosion of lamina of dorsum and floor of pituitary fossa and also some thinning of anterior clinoid processes.

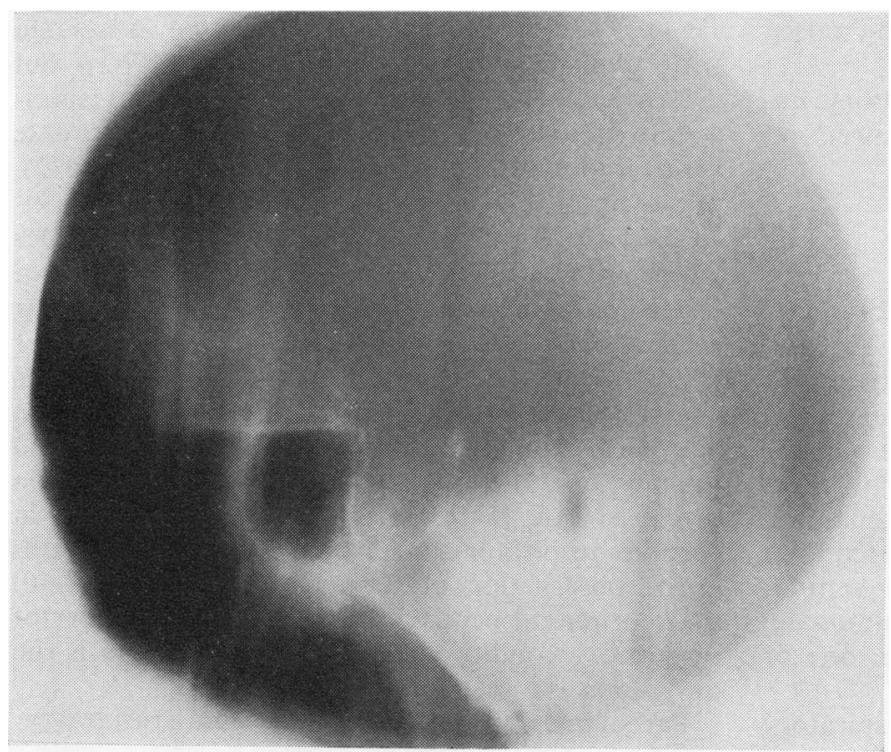

Fig 2 Patient No 6. Erosion of lamina dura of dorsum sellae and a deep sella. 


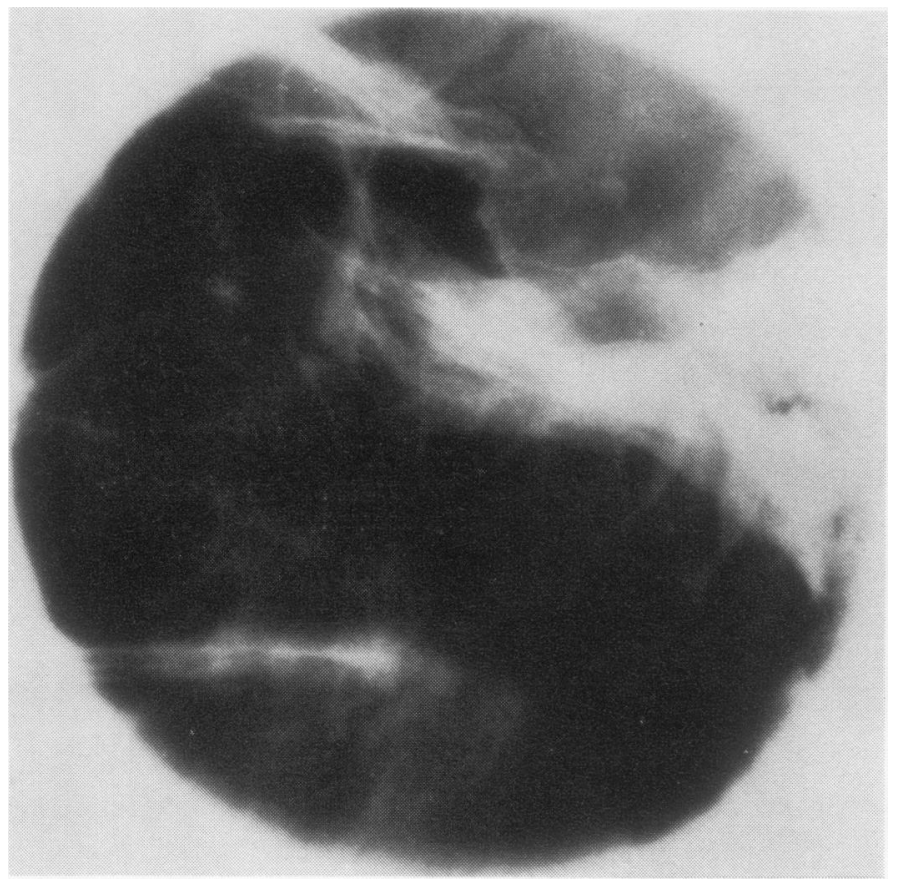

Fig 3 Patient No 2. Thinning of lamina dura of floor and erosion of lamina dura of dorsum sellae.

capnic. All seven chronically hypercapnic and one intermittently hypercapnic patient had radiological abnormalities of the pituitary fossa (table 1). These changes are those included in the category I sella turcica changes in raised intracranial pressure described by Du Boulay and El Gammall (1966). In addition, one patient showed thinning of the anterior clinoid processes and planum sphenoidale, and one showed a large deep sella; these are both features that may be seen in longstanding raised intracranial pressure.

A group matched for age and respiratory impairment, but without hypercapnia, showed no sella changes (table 2).

\section{Discussion}

Patients selected on a basis of chronic or intermittent hypercapnia will have severe lung disease. None of our patients had an FEV 1 greater than one litre, and all were dyspnoeic on exertion. Despite the respiratory impairment one patient was initially referred to a psychiatrist for worsening depression, and another patient presented to a neurologist with headache; both patients required ventilation. Two other patients required ventilation, five patients had episodes of cor pulmonale, and two had papilloedema at some stage, one of whom developed optic atrophy (case 6).

The mechanism of papilloedema in respiratory failure and the cause of oedema in cor pulmonale have been extensively discussed. Papilloedema occurs in $10 \%$ of patients with respiratory failure (Simpson, 1954). It does not appear to be due to raised venous pressure alone as this may be substantially raised without papilloedema (Hinshaw and Rutledge, 1942) and, conversely, it may occur in the absence of raised venous pressure in chronic respiratory insufficiency (Manfredi et al, 1961). Primary polycythaemia .may be associated with papilloedema (Silverstein et al, 1962), but polycythaemia is not a constant finding in respiratory failure (table 1). Hypoxia produces an increase in cerebral blood flow (Lennox and Gibbs, 1932), but hypercapnia is a more potent stimulus to increased cerebral blood flow (Fieschi and Des Rosiers, 1976). Hypercapnia has also been shown experimentally in the brain to increase vascular permeability, resulting in brain oedema (Cutler et al, 1966). The subject of respiratory acidosis and acid-base balance in the cerebrospinal fluid has been extensively reviewed by Katzman and Pappius (1973).It would appear that hypercapnia is the major factor producing papilloedema in chronic respiratory insufficiency. Supporting this is the observation of Campbell and Short (1960) that peripheral oedema may occur in a number of respiratory conditions in which hypercapnia is the only constant feature.

Pathological evidence in chronic respiratory 
Table 1 Summary of results of lateral radiography of the skull and coned view of pituitary fossa

\begin{tabular}{|c|c|c|c|c|c|c|c|c|c|c|c|}
\hline $\begin{array}{l}\text { Case } \\
\text { no }\end{array}$ & Sex & Age & $\begin{array}{l}\text { Minimum } \\
\text { duration of } \\
\text { hypercapnia }\end{array}$ & $\begin{array}{l}\text { Clinical } \\
\text { diagnosis }\end{array}$ & $F E V_{1} / V C$ & $\begin{array}{l}\text { Predicted } \\
F E V_{1} / V C\end{array}$ & $\begin{array}{l}\text { Mean } \\
\mathrm{PaCO}_{2} \\
\mathrm{kPa} \\
(\mathrm{mmHg})\end{array}$ & $\begin{array}{l}H b \\
(g / d l)\end{array}$ & $P C V$ & Clinical presentation & $\begin{array}{l}\text { Skull } \\
\text { radiograph* }\end{array}$ \\
\hline 1 & $\mathbf{M}$ & 51 & 1 year & $\begin{array}{l}\text { Chronic } \\
\text { bronchitis }\end{array}$ & $0 \cdot 6 / 1 \cdot 9$ & $2 \cdot 7 / 3 \cdot 5$ & $\begin{array}{l}7 \cdot 13 \\
(53 \cdot 5)\end{array}$ & $15 \cdot 1$ & 0.46 & Breathlessness & A, B \\
\hline 2 & $\mathbf{F}$ & 52 & $1 \frac{1}{2}$ years & $\begin{array}{l}\text { Chronic } \\
\text { bronchitis }\end{array}$ & $0.7 / 1.9$ & $2 \cdot 3 / 2 \cdot 7$ & $\begin{array}{l}8 \cdot 00 \\
(60 \cdot 0)\end{array}$ & $14 \cdot 5$ & 0.43 & $\begin{array}{l}\text { Depression. Ventilated } \\
\text { 1976. Referred by } \\
\text { psychiatrists }\end{array}$ & A, B \\
\hline 3 & $\mathbf{F}$ & 64 & 2 years & $\begin{array}{l}\text { Chronic } \\
\text { bronchitis }\end{array}$ & $0 \cdot 6 / 1 \cdot 2$ & $2 \cdot 1 / 2 \cdot 8$ & $\begin{array}{l}6 \cdot 67 \\
\text { Inter- } \\
\text { mittent } \\
(50)\end{array}$ & $14 \cdot 4$ & 0.45 & $\begin{array}{l}\text { Headaches leading to } \\
\text { coma. Ventilated } 1975 \text {. } \\
\text { Referred by } \\
\text { neurologists }\end{array}$ & B, C \\
\hline 4 & $\mathbf{F}$ & 56 & 6 months & $\begin{array}{l}\text { Chronic } \\
\text { bronchitis. } \\
\text { Emphysema }\end{array}$ & $0 \cdot 6 / 1 \cdot 0$ & $1 \cdot 8 / 2 \cdot 2$ & $\begin{array}{l}6 \cdot 67 \\
(50)\end{array}$ & $16 \cdot 1$ & 0.49 & $\begin{array}{l}\text { Respiratory failure } \\
\text { and cor pulmonale }\end{array}$ & B, C \\
\hline 5 & $\mathbf{M}$ & 54 & 6 months & $\begin{array}{l}\text { Chronic } \\
\text { bronchitis }\end{array}$ & $0 \cdot 5 / 1 \cdot 1$ & $2 \cdot 9 / 3 \cdot 8$ & $\begin{array}{l}7 \cdot 87 \\
(59)\end{array}$ & 14.9 & 0.43 & Respiratory failure & $\mathbf{A}$ \\
\hline 6 & $\mathbf{M}$ & 60 & 13 years & $\begin{array}{l}\text { Chronic } \\
\text { bronchitis }\end{array}$ & $0 \cdot 9 / 2 \cdot 6$ & $3 \cdot 4 / 4 \cdot 5$ & $\begin{array}{l}7 \cdot 20 \\
(54)\end{array}$ & $16 \cdot 0$ & 0.46 & $\begin{array}{l}\text { Papilloedema and cor } \\
\text { pulmonale. } \\
\text { Subsequent optic } \\
\text { atrophy }\end{array}$ & B \\
\hline 7 & $\mathbf{F}$ & 55 & 10 years & $\begin{array}{l}\text { Chronic } \\
\text { bronchitis }\end{array}$ & $0 \cdot 9 / 2 \cdot 1$ & $2 \cdot 2 / 2 \cdot 8$ & $\begin{array}{l}9 \cdot 00 \\
(67 \cdot 5)\end{array}$ & $17 \cdot 5$ & 0.51 & $\begin{array}{l}\text { Died } 1977 \text {. Ventilated } \\
\text { 1966. Developed } \\
\text { papilloedema and } \\
\text { cor pulmonale } 1976\end{array}$ & B \\
\hline 8 & $\mathbf{F}$ & 70 & 9 months & $\begin{array}{l}\text { Chronic } \\
\text { bronchitis }\end{array}$ & $0 \cdot 65 / 2 \cdot 0$ & $1 \cdot 7 / 2 \cdot 0$ & $\begin{array}{l}7 \cdot 73 \\
(58)\end{array}$ & $14 \cdot 6$ & 0.48 & Respiratory failure & $\mathbf{A}, \mathbf{B}$ \\
\hline 9 & $\mathbf{M}$ & 60 & 6 months & $\begin{array}{l}\text { Chronic } \\
\text { bronchitis. } \\
\text { Kyphosis }\end{array}$ & $0 \cdot 7 / 1 \cdot 7$ & $2 \cdot 6 / 3 \cdot 4$ & $\begin{array}{l}6 \cdot 40 \\
\text { Inter- } \\
\text { mittent } \\
(48)\end{array}$ & $15 \cdot 9$ & $0 \cdot 50$ & $\begin{array}{l}\text { Respiratory failure. } \\
\text { Ventilated } 1977\end{array}$ & Normal \\
\hline 10 & M & 46 & 6 months & $\begin{array}{l}\text { Chronic } \\
\text { bronchitis }\end{array}$ & $0 \cdot 9 / 1 \cdot 7$ & $3 \cdot 4 / 4 \cdot 6$ & $\begin{array}{l}6 \cdot 27 \\
\text { Inter- } \\
\text { mittent } \\
(47)\end{array}$ & $14 \cdot 8$ & 0.47 & Cor pulmonale & Normal \\
\hline
\end{tabular}

*A = Thinning of lamina dura $\mathbf{B}=$ Erosion of lamina dura of dorsum; $\mathrm{C}=$ Erosion of pituitary fossa floor.

In both tables the $\mathrm{FEV}_{1}$ and $\mathrm{PaCO}_{2}$ values were recorded as outpatients. The $\mathrm{CO}_{2}$ value is the mean of two arterial samples and two corrected oxygenated mixed venous rebreathing samples over a six-month period.

Table 2 Relative data on control patients

\begin{tabular}{lll}
\hline & Hypercapnic patients & Controls \\
\hline Sex & 5 men : 5 women & 6 men : 2 women \\
Mean age & $56 \cdot 8$ years & 60 years \\
Mean $\mathrm{FEV}_{1}(1)$ & $0 \cdot 7$ & $0 \cdot 8$ \\
${\text { Mean } \mathrm{PaCO}_{2}}$ & $7 \cdot 3 \mathrm{kPa}(55 \mathrm{mmHg})$ & $5 \cdot 5 \mathrm{kPa}(41 \mathrm{mmHg})$ \\
\hline
\end{tabular}

insufficiency would appear overwhelmingly to support the role of raised intracranial pressure in the production of papilloedema. Engorgement of cerebral surface veins and flattening of convolutions (Beaumont and Hearn, 1948), cerebellar pressure cone (Simpson, 1954), and brain stem distortion (Miller et al, 1960) have all been shown. Despite this evidence Spalter and Bruce (1964) suggested that papilloedema is produced by local changes in the retinal vasculature in response to the increased blood flow of hypercapnia. They did not consider intracranial pressure an important factor. Our radiological findings would suggest the contrary; in our patients raised intracranial pressure would appear a frequent occurrence in chronic hypercapnia with or without papilloedema.
Campbell and Short (1960) suggested that in some cases of cor pulonale respiratory acidosis leads to increased hydrogen ion secretion in the renal tubules, increased reabsorption of sodium and bicarbonate, and expansion of the extracellular fluid (ECF). This would be an additional factor contributing to brain oedema. The mechanism by which brain oedema produces papilloedema has recently been the subject of an editorial (British Medical Journal, 1978). From the clinical standpoint the clinician should be aware that a patient with an eroded pituitary fossa and papilloedema or headaches may be suffering from chronic respiratory failure alone.

We believe there is a diagnostic analogy between respiratory and renal failure. In patients presenting with renal failure a hand radiograph sometimes shows an osteodystrophy and is a useful indicator of chronicity (Doyle, 1972). It appears that the chronicity of hypercapnia may be diagnosed from a radiograph of the pituitary fossa. We have seen no patients with clearcut radiological changes whose $\mathrm{PaCO}_{2}$ has subsequently reverted to normal, while two patients who have been intermittently 
hypercapnic have no radiological abnormality yet. Further studies will be necessary to determine the minimum duration of hypercapnia required to produce these changes.

We thank Drs G N Chandler and G F Edwards for permission to study their patients and Dr W Whitaker and Mrs Jacqueline Buck for their help.

\section{References}

Beaumont, G E, and Hearn, J B (1948). A case of reversible papilloedema due to heart failure. British Medical Journal, 1, 50.

British Medical Journal (1978). Parson's papilloedema. 1, 263-264.

Campbell, E J M, and Howell, J B L (1960). Simple rapid methods of estimating arterial and mixed venous $\mathrm{PCO}_{2 .}$. British Medical Journal, 1, 458-462.

Campbell, E J M, and Short, D S (1960). The cause of oedema in "cor pulmonale". Lancet, 1, 11841186.

Cotes, J E (1973). Lung Function, 3rd edition. Blackwell, Oxford and Edinburgh.

Cutler, R W, Barlow, C F, and Lorenzo, A V (1966). The effect of brain-cerebrospinal fluid diffusion gradients on the determination of extracellular space in cat brain. Journal of Neuropathology and Experimental Neuropathology, 26, 167-169.

Doyle, F H (1972). Radiological patterns of bone disease associated with renal glomerular failure in adults. British Medical Bulletin, 28, 220-224.

Du Boulay, G H, and El Gammall, T (1966). The classification, clinical value and mechanism of sella turcica changes in raised intracranial pressure. British Journal of Radiology, 39, 422-442.

Fieschi, C, and Des Rosiers, M (1975). Cerebral blood flow measurements in stroke. In Cerebral Arterial
Disease, ed R W Ross Russell, pp 85-106. Churchill Livingstone, Edinburgh.

Hinshaw, H C, and Rutledge, D I (1942). Lesions in superior mediastinum which interfere with venous circulation. Journal of Laboratory and Clinical Medicine, 27, 908-916.

Katzman, R, and Pappius, H M (1973). Brain Electrolytes and Fluid Metabolism. Williams and Wilkins, Baltimore.

Lennox, W, and Gibbs, E L (1932). Blood flow in brain and leg of man and changes induced by alteration of blood gases. Journal of Clinical Investigation, 2, 1155-1177.

Manfredi, F, Merwarth, C R, Buckley, C E, Seiker, H O (1961). Papilloedema in chronic respiratory acidosis. American Journal of Medicine, 30, 175180.

Medical Research Council (1965). Definition of classification of chronic bronchitis. Lancet, 1, 775779.

Miller, R D, Bastron, J A, and Kearns, T P (1960). Papilledema in patients with severe pulmonary emphysema. Diseases of the Chest, 37, 350-355.

Newton, D A G, and Bone, I (1978). Papilloedema and optic atrophy in chronic hypercapnia. British Journal of Diseases of the Chest. In press.

Silverstein, A, Gilbert, H, Wasserman, L R (1962). Neurological complication of polycythemia. Annals of Internal Medicine, 57, 909-916.

Simpson, T (1954). Acute respiratory infections in emphysema. British Medical Journal, 1, 297-301.

Spalter, H F, and Bruce, G M (1964). Ocular changes in pulmonary insufficiency. Transactions of the American Academy of Ophthalmology and Otolaryngology, 68, 661-676.

Requests for reprints to: Dr D A G Newton, St James's University Hospital, Leeds LS9 7TF. 